Western Kentucky University

TopSCHOLAR®

GFCB Working Paper Series

Gordon Ford College of Business Documents and Special Projects

6-11-2005

\title{
China Financial Research: A Review and Synthesis
}

Kam C. Chan

Western Kentucky University, johnny.chan@wku.edu

Hung-Gay Fung Dr.

University of Missouri-St. Louis, fungh@umsl.edu

Samanta Thapa

Western Kentucky University, samanta.thapa@wku.edu

Follow this and additional works at: https://digitalcommons.wku.edu/gfcb_wrkg_pap

Part of the Corporate Finance Commons, E-Commerce Commons, Finance and Financial Management Commons, International Business Commons, and the Management Information Systems Commons

\section{Recommended Citation}

Chan, Kam C.; Fung, Hung-Gay Dr.; and Thapa, Samanta, "China Financial Research: A Review and Synthesis" (2005). GFCB Working Paper Series. Paper 4.

https://digitalcommons.wku.edu/gfcb_wrkg_pap/4

This Article is brought to you for free and open access by TopSCHOLARß. It has been accepted for inclusion in GFCB Working Paper Series by an authorized administrator of TopSCHOLARß. For more information, please contact topscholar@wku.edu. 


\title{
China Financial Research: A Review and Synthesis
}

\author{
Kam C. Chan* \\ Department of Finance \\ Western Kentucky University \\ Bowling Green, KY 42101
}

Tel: (270) 745-2977; fax: (270) 745-5284

Email: Johnny.Chan@wku.edu

\author{
Hung-Gay Fung \\ College of Business Administration \& \\ Center of International Studies \\ University of Missouri-St. Louis \\ 8001 Natural Bridge Road \\ St. Louis, MO 63121
}

Tel: (314) 516-6374; Fax: (314) 516-6420

Email: fungh@msx.umsl.edu

\author{
Samanta Thapa \\ Department of Finance \\ Western Kentucky University \\ Bowling Green, KY 42101 \\ Tel: (270) 745-2977; fax: (270) 745-5284 \\ Email: Samanta.Thapa@wku.edu
}

June 11, 2005

*Corresponding author. We acknowledge the helpful comments from two anonymous referees. We are responsible for any remaining errors. 


\title{
China Financial Research: A Review and Synthesis
}

\begin{abstract}
We review the financial research on China as a transitional economy over the past fifteen years or so. This review sheds light on several important issues that are pertinent for an emerging financial market - how regulation can affect the prices of different financial assets; how and why markets are segmented; corporate governance effects between major and minor shareholders in an emerging market; the importance of a bank-based financial system; interactions between the financial market and the goods market; how market participants can complete the market; and how an emerging financial market emulates established markets and evolves over time. Many unexplored financial issues remain unexplored, and more research is warranted into, what theories are at work, and what are missing.
\end{abstract}

Key words: China’s Financial Research, imperfect markets, and emerging market

JEL classification: G1, G2, and G3. 


\section{China Financial Research: A Review and Synthesis}

\section{Introduction}

Economic reforms to move China from a planned to a market-oriented economy began in 1978. In its early economic reforms, the Chinese government focused on specific economic policies, such as privatizing the state ownership system and promoting international trade, and to stimulate economic growth. In the late 1980s, China paid more attention to improving its financial system to sustain a successful economic process. Banking sector reform has received much attention in the popular press because of large non-performing loans inherited from the earlier regime; China's commitment to open up its banking sector as a new member of the World Trade Organization started in 2001.

Some groundbreaking initiatives in the financial markets include the establishment of (1) two stock exchanges with over 1,300 listed companies (the Shenzhen Stock Exchange followed the Shanghai Stock Exchange in 1991), (2) several futures exchanges trading agricultural and metal commodity futures contracts, and (3) a foreign exchange market that allows trading of the Chinese Renminbi with several currencies.

Financial issues related to China are interesting and deserve attention, because they exemplify many intriguing characteristics of an emerging financial market, which differs from the western well-developed financial markets. Examination of these issues sheds light on which finance theories are operative and which require refining to be applied to this important emerging financial market. The issues cover several areas. First, we explore the characteristics of an imperfect financial market, where heavy government regulation affect prices of different financial assets. As a result, financial markets are basically segmented. Second, corporate governance is an important topic in China because of the potential conflict between major 
shareholders and minority shareholders. Third, as a typical transitional economy, China is a bank-based economy despite its rapid development of two stock exchanges that enable Chinese firms to raise external funds. It is interesting to examine some potential issues of such a bankbased system. Fourth, as China is an emerging market, we can easily see interactions between financial and goods markets. These interactions are not so apparent in a well-developed financial market. Fifth, we discuss some opportunities available for market participants to complete the market to overcome impediments of the financial market in China with new innovations and instruments. This development is particularly apparent in the China's managed foreign exchange market. Finally, we shed light on how China's financial market integrates with the global market, a result of globalization.

Since the early 1990s, rapid financial development in China has prompted many academic research studies. The objective of this paper is to provide a critical review and synthesis of the financial research on China over the last fifteen or so years. We discuss what issues have been examined and what have not, thus shedding some light on the possibilities for future research. We provide a wide discussion on financial research about China, and include many studies in the literature, but do not claim to be exhaustive. Beyond a traditional search of the financial literature, we use ABI/INFORM, EBSCO, and the Social Science Citation Index as our basis on this review and synthesis study. As our review primarily focuses on published scholarly papers on financial research, we do not include articles focusing on other business disciplines such as accounting, economics, or management. Findings are presented in China's financial development, research, and interesting patterns as follows. 


\section{Imperfect Market and Market Segmentation}

The Chinese stock market has expanded rapidly since establishment of the Shanghai Stock Exchange (SHSE) in December 1989 and the Shenzen Stock Exchange (SZSE) in April

1991. As one of the largest emerging markets in the world, China has provided a rich environment for investigation of equity price behavior in an emerging market. The Chinese equity market has two classes of ownership-restricted shares: A-shares, which can be owned and traded only by the Chinese citizens, and B-shares, which can be owned and traded by foreigners and local Chinese residents who hold foreign currencies after February 2001.

Research in this relationship of A- and B-share pricing behavior has taken two main tracks: explanation of the pricing behavior of the Chinese stock markets and B-share discounts relative to A-share in terms of market fundamentals. The B-share market is the result of the Chinese regulation. Both research directions reflect the impact of government regulations on the A- and B-share markets.

\subsection{The pricing behavior and efficiency of the Chinese stock markets}

The early studies on pricing behavior in China are modeled on U.S. research. That is, researchers investigate whether a similar pattern of pricing behavior is observable in the Chinese market as in the U.S. market. There are several strands of studies in the context of pricing behavior and market efficiency.

The first strand relates primarily to uses daily or sometimes weekly A- and B-share market index to investigate the pricing behavior. Laurence, Cai, and Qian (1997) and Liu, Song, and Romily (1997) provide early studies on the weak-form efficiency of the Chinese stock market. Using serial correlation tests, Laurence et al conclude that the domestic A-share markets are weak-form efficient, while the B-share market in Shanghai is not efficient. Liu et al find (1) 
each stock exchange share price index follows a random walk process; (2) there is cointegration between these two indexes; and (3) there is bidirectional causality between these two indexes.

Su and Fleisher (1998) investigate the risk-return behavior of the Chinese stock market in light of government regulation. Relative to the markets in the developed countries, they find that risk adjusted return in Chinese stock market is low and volatility of returns is very high and time-varying. Further, A-share market is more volatile than B-share market. Long, Payne and Feng (1999) investigate the impact of information transmission on market efficiency and pricevolume relation in Class A and B-shares listed in Shanghai stock exchange. Long et al argue that presence of institutional investors tends to disseminate information smoothly, and hence, Bshareholders is more informed than A-shareholders. The implication is that there may be greater efficiencies and lower price-volume relations in B-share market (i.e., correlation between pricevolume in A-share market is greater than in B-share market). However, Long et al provide evidence that there is no significant difference in price-volume correlations between A- and Bshares.

Friedmann and Sandford-Kohle (2000) analyze volatility dynamics using GARCH type models in the Chinese stock market. Specifically, they investigate asymmetric impact of good and bad news, relatively long nontrading days, and reintroduction of daily price change limit on volatility in A- and B-share market. They find that bad news increase volatility more than good news in A-share indices and Composite indices, whereas good news increases volatility more than bad news in B-share indices. They also find that number of nontrading days has a significant and positive effect on volatility for A-share and Composite indices, but not for Bshare indices. Overall, Friedmann and Sandford-Kohle report different volatility dynamics in A and B-share markets reflecting segmentation of these markets. Yeh, Lee, and Pen (2002) use a 
multivariate GARCH model to analyze the information content in lagged premiums of Chinese A-share over B-share. Lagged premiums are found to have certain predictive power over the future returns and volatility of both A- and B-shares. An increase in the premium ratio of Ashare will predict a rise in the return of A-share and a fall in the return of B-share. In addition, unexpected changes in the premium ratio of the A-share over B-share price contribute to the return volatility of both A-share and B-share. The results suggest return and volatility are predictable by the historical premiums of A-share over B-share.

Wang, Liu, and Wang (2004) investigate interactions between Chinese A- and B-share traded on the Shanghai stock exchange and the Shenzhen stock exchange. Wang, Liu, and Wang find that there is a causal relation from B-share markets to A-share markets in the second moment (variance). Wang, Liu, and Wang argue that A- and B-share investors have different investment objectives and scopes and hence, there exist stronger links between shares of the same type, i.e., between the two A- and B-share markets, than those between shares of different types.

Studies in the second strand consider more information beyond A- and B-share index. The additional information may include bid/ask spread, volume, volatility, open/close prices. Xu (2000) provides a good description of the auction principles, clearance, settlement, and depository facilities in China, and also models the return/volatility relationship in an autoregression framework with results mirroring those in the U.S. Lee and Rui (2000) study contemporaneous and causal relationships among trading volume, stock returns, and return volatility using the stock market indices of China, Hong Kong, and the U.S. Their major findings are that trading volume does not predict stock market returns in China, and U.S. returns help predict Chinese stock market returns. In a similar study, Chen, Lee, and Rui (2001) use a 
different methodology to investigate the relation between stock return and volatility. The results of GARCH and EGARCH models suggest there is a time-varying volatility but no relation between expected return and expected risk level. Both Lee and Rui (2000) and Lee, Chen, and Rui (2001) suggest that the stock returns in China do not follow a random walk, and U.S.-style asset pricing models do not seem to describe the risk-return relationship in the Chinese stock market. Using daily return volatility as seen in open-close quotes, Fung and Leung (2002) investigate the relationship of volatility with the bid-ask spread and trading volume in the A- and B-share markets. The relationships in each market are becoming more similar over time, suggesting a trend toward integration. Fung and Leung argue that forces including enforcement of security laws and institution of accounting regulations that can potentially mitigate segmentation between the two markets. Investors can also arbitrage through different nominal trading accounts in Hong Kong or in the U.S. Su (2003) investigates whether corporate earnings disclosures convey information in the Chinese stock market. Using event study methodology and 183 corporate earnings announcement between 1997 and 1998, Su reports significant abnormal returns for A-share market and little or no abnormal returns for B-share market on the announcement date.

The third strand of literature examines the issue on information flows across markets. The information flow between the red-chip stock market (Chinese companies incorporated in Hong Kong and listed on Stock Exchange of Hong Kong) and the H-share market (overseas companies listed on Stock Exchange of Hong Kong and subscribed for and traded in Hong Kong dollars) is examined in Poon and Fung (2000). Using an EGARCH-M model (a variation of a conditional heteroskedastic autoregressive model), Poon and Fung find that, for Chinese company stocks, red-chip stocks process information more quickly than H-shares. In a similar study, Xu and 
Fung (2002) study the information flows between China-backed stocks dual-listed in Hong Kong and New York. An interesting result is that stocks listed on the domestic market (Hong Kong) carry more weight in the price determination, while stocks in the offshore market (New York) are more influential in a volatility spillover impact. Using a different perspective, Yeh and Lee (2000) investigate the asymmetric impact of good and bad news on return volatility of stock returns in Hong Kong, Taiwan, Mainland China (Shanghai and Shenzhen stock markets). Yeh and Lee also examine how these markets interact with each other following a 'shock' (good or bad news) in one of these markets. Yeh and Lee find that in Taiwan and Hong Kong markets, the impact of bad news is greater than the impact of good news on expected volatility, whereas in the Shanghai and Shenzhen markets it is just the opposite. Wang, Kutan, and Yang (2004) examine information flows across different sectors of Chinese stocks. Wang, Kutan, and Yang find that sectors are highly integrated, and the industrial sector is the most influential in both the Shanghai and Shenzhen stock exchanges. The implication of these results is an easy spillover from one sector to another if there is financial trouble.

Fourth, many studies investigate the predictability of future stock returns over short, intermediate, and long-term horizon based on past stock returns in the developed stock markets. Kang, Liu, and Ni (2002) investigate the predictability of future returns of A-share market returns based on past returns in the Chinese stock markets. Using weekly data on stock prices covering the period 1993-2000, Kang et al document some significant short-term contrarian and intermediate-horizon momentum profits. Kang et al suggest that the main sources of these profits are the overreaction of the stocks to firm-specific information and lead-lag structure. Wang and Chin (2004) study whether returns on Chinese stock markets are predictable by examining the profitability of various portfolio investment strategies. They construct five equal sized portfolios 
based on lowest returns (losers) to highest returns (winners) and also five equal sized portfolios based on lowest trading volume (low-volume) to highest trading volume (high-volume). The intersections from these two sorted portfolios results in 25 two-way sorted portfolios. They compute average monthly returns for these portfolios and find that conditional on past returns, low volume stocks have higher returns than high volume stocks; the effect of past trading volume on returns are different for past winners and losers. For past winners, the difference in returns between low-volume and high-volume stocks is larger than for past losers. In short, they provide evidence of return patterns, which implies return predictability in the Chinese stock market.

In general, there are many studies on the pricing behavior of Chinese equity market. The overall results are limited by the availability of daily data. There are few intradaily studies. Some of the findings in the Chinese stock market are similar to those in the U.S., and some other results are very different. These mixed findings indicate that China indeed has a different economic, institutional, and market microstructure from the U.S. This is likely because of the underlying impact of Chinese government regulations in the process. The earlier studies in midand late-1990s use standard time series methodologies and stock market index data while the more recent studies become more individual stock and industrial sector data with more sophisticated research methodologies. As there are ample research in this area, future research is likely to move toward more intradaily studies and explore issues have not been researched before. 
2.2 Market segmentation and explanations for price differentials among different classes of stocks

China's emerging financial market is clearly imperfect and incomplete; we see many market impediments such as transaction costs, all sorts of taxes, and information asymmetry. The Chinese government has played an important role in transforming an opaque financial system into a relatively more transparent one by requiring more disclosure of information to the public. We must ask whether regulations on more information release and improved transparency will exacerbate or mitigate the volatility of security prices. Two different results seem possible.

Government policies can create financial market segmentation, which gives rise to mispricing. The Chinese government restricts free flows of capital in the capital account and intends to protect domestic firms from foreign control. It has thus created the A-share market (for domestic investors) and the B-share market (for foreign investors). Researchers such as Kwok and Chui (1998), Fung, Lee, and Leung (2000), and Chan, Cheng, and Fung (2001) conclude that these markets are segmented. That is, the A- and B-share markets have their own pricing dynamics. Although the shares have identical claims on a firm's cash flows, there are price differences between A- and B-share. Gordon and Li (2003) have argued that the segmented features of Chinese financial markets enable the Chinese government to best perform the social welfare functions (achieve particular social goals).

B-share and H-share typically trade at a discount to their A-share counterpart although they have the same dividend and voting rights. This discount effect in China is contrary to the experience in other countries, where foreign shares typically trade at a premium. Different models are proposed to explain the discount phenomenon include: a demand differential model [Sun and Tong (2000), and Chen, Lee, and Rui (2001)]; information asymmetry model 
[Chakravarty, Sarkar and Wu (1998), Kwok and Chui (1998), Su and Fleisher (1998), Sun and Tong (2000), Chen, Lee, and Rui (2001), Karolyi and Li (2003), and Yang (2003)]; a liquidity differential model [Bailey (1994), Bergstrom and Tang (2001), Chen, Lee and Rui (2001), and Karolyi and Li (2003)]; and a risk differential model [Bailey (1994), Su (1999), Fung, Lee, and Leung (2000), Chen, Lee, and Rui (2001), Fernald and Rogers (2002)].

The elimination of market impediments, on the other hand, would realign security prices according to the law of one price. In the B-share market for foreign investors, more information is disclosed to the public because of more stringent disclosure conditions and Western-style auditing. Chinese firms listed on the Hong Kong exchange in the form of H-share also must meet even more stringent accounting and disclosure requirements [Poon and Fung (2000)]. He, Wu, and Chen (2003) revisit the return and volatility patterns of A- and B-share in the late 1990s and find that the difference in A- and B-share returns is non-existent.

The price differential between the A- and B-share markets begins to disappear over time for a variety of reasons. Investors may find effective ways to arbitrage between the A- and Bshare markets [Fung and Leung (2002)]. The government has allowed domestic investors with foreign currency to invest in the market since February 2001; the relaxation of some of the arbitrary impediments in the market will result in a diminishing price discount for B-share [Karolyi and Li (2003)]. The implementation of Qualified Financial Institutional Investor (QFII) program in early 2003 allows foreign investors to invest in the once-restricted A-share market, opening the door for a possibility of formal arbitrage between the A- and B-share markets [Fung and Liu (2004)]. Thus, the price differential puzzles among various classes of shares become less important as China removes the ownership restriction and the market arbitraging activities. 


\subsection{Market impediments and governmental factor}

Chen (2004) investigates the determinants of capital structure of Chinese firms as espoused by theories developed in the U.S. Chen finds that neither the trade-off nor the pecking order seem to explain capital choices fully. For example, the negative relationship between profitability and leverage seem to support the pecking order, but Chen argues that this may be due to institutional and financial constraints rather than reasons provided by the pecking order theory such as underinvestment problems and mispricing of new projects. Chen suggests that Chinese firms prefer equity financing to debt, because China's bond market is still underdeveloped and state owned Chinese banks are stretched thin to provide long-term loans; substantial stock price appreciation in the secondary market; firms seem to consider equity source as 'free' financing because there is no adequate legal enforcement system to protect individual investors, tax effects of debt as predicted by trade-off theory is rather limited. Hence, in China, there seem to be a new pecking order: retained earnings, new equity and long- term debt.

Along with establishment of stock markets in China came privatization of previously state-owned enterprises beginning in the early 1990s. The privatization process occurs through a share issuing process. There are several studies in this area. Otchere and Zhang (2001) use both accounting and stock market information to examine the performance of privatized SOEs. They find that privatization signaled a change in the industry of the privatized firms. As a result, stock prices of competitors in the same industry reacted negatively upon privatization announcements. Privatized firms also did better than their counterparts in operating performance. There is no evidence, however, that the proportion of government ownership explains the returns of the privatized firms. Sun, Tong, and Tong (2002) offer results to support the positive effect of 
government ownership on partially privatized firms to some degree. Essentially, the relationship takes on an inverted U-shaped pattern, so it seems that there is an optimal level of government ownership. Sun and Tong (2003) provide additional evidence to suggest that privatization improves SOEs' earnings ability, real sales, and worker productivity. Legal person ownership, rather than government and foreign ownership, is positively related to firm performance. In another privatization study, Wei et al (2003) find similar results, but not a significant change in profitability in the full sample. For privatized firms whose private investors have 50\% voting control, performance in terms of profitability, sales, and workers' productivity improves. The privatization studies overall offer mixed results. Sun, Tong, and Tong (2002) suggest an optimum; that is, too much government control is bad for privatized firms, and too little may indicate a lack of government political support. Other studies do not suggest this important implication.

Fung (2005) illustrates how the Chinese firms use trade and foreign direct investments as options to overcome market impediments imposed by the Chinese government. The large trade report discrepancy between China and Hong Kong contributes to the large inflows of hot money from tax haven countries to China in an attempt to explore differential tax treatment between domestic and foreign firms.

\section{Corporate Governance Issue and IPOs}

As the stock market in China continues to develop, more companies begin to issue their shares to the general public. Naturally, the performance of these newly listed companies receives much public attention. The related initial public offerings (IPOs) and corporate governance research begin to emerge. 


\subsection{Corporate governance}

Another interesting pattern in the Chinese capital market experience is corporate governance, which illustrates the potential conflict between shareholders and managers, and the conflict between large and small stockholders.

Chen (2001) examines the impact of ownership structure on corporate performance of Chinese manufacturing firms. Chen correlates Tobin's Q, used as a measure for the corporate performance, with ownership concentration, as measured by the fraction of shares held by the single largest shareholder and the fraction of shares held by the top ten shareholders. Chen uses five categories of ownership: state owned shares, state solely owned institutions, shares owned by domestic institutions, shares held by the top management, shares that can be freely traded on the stock exchanges. Since corporate performance is also affected by other factors, Chen uses a set of control variables: age of firms, Debt/Equity ratio, sales growth, firm size and return on assets. Using data for 434 manufacturing companies listed in Chinese stock exchange, Chen finds that ownership concentration (top ten shareholders) is strongly related to Tobin's Q and the impact is positive as suggested by existing literature. Chen also finds that institutional and managerial shareholdings are significant and positively related with Tobin's Q whereas state owned shares are negatively related.

Fung and Leung (2001) discuss the benefits of China's financial liberalization in corporate governance. That is, the competitiveness and efficiency of the stock market should help align stockholders’ interest with managers, reducing agency costs. In addition, deregulated Chinese banks can monitor corporate activities and improve the efficiency of corporations.

Burkart, Panunzi, and Shleifer (2003) demonstrate that in environment that provides the least legal protection to stockholders major shareholders are likely to seek control of the firm, 
resulting in conflict between large and small stockholders, while the agency sort of conflict between stockholders and management is more likely in an environment that protects investors better. In China, investors have little legal protection, so we tend to see a significant wealth expropriation from minority stockholders to major shareholders [Watanabe (2002)]. In many Chinese firms, CEOs also act as board chair, apparently ignoring the separation of the control and monitoring mechanisms. Liang and $\mathrm{Li}$ (2003) find that the dual CEO-chairman of the board role is optimal in a study of 228 private Chinese firms. Lam and Du (2004) offer results suggesting that there is a significant negative relation between voluntary disclosure based on US GAAP with certification of a credible audit firm and the variation of risk-adjusted returns.

The government is the major stockholder in state-owned enterprises. $\mathrm{Xu}$ and Wang (1999), Wei, Varela, and Hassan (2002), and Sun and Tong (2003) demonstrate the inefficiency of the state-owned enterprises in their lack of governance, while a large holding from nonfinancial institutional investors may have a positive effect on firm performance. Stijn and Laeven (2003) demonstrate in 44 countries that more secure property rights lead to greater financial development and economic growth. Allen, Qian, and Qian (2005) provide partial evidence in support of the hypothesis and suggest that competition in the goods market is an important factor in China's corporate governance.

Because floatable and non-floatable shares have different trading values, Huang and Fung (2004) argue that the major shareholders with non-floatable shares will try to maximize their book values through the issue of non-floatable shares in order to exploit the liquidity premium (i.e., the price differential between the market value of the floatable shares and the book value of the non-floatable shares). As a result, they can explain three patterns of behavior in China- why Chinese firms prefer floatable equity financing to other types of financing; why no mergers and 
acquisitions (M\&As) are observed between listed companies; and why we observe frequent sequential moves of Chinese firms from an initial M\&As to equity financing of floatable shares.

It is interesting but puzzling to observe a weak governance mechanism in the sense of traditional western expectations, and the least property rights protection in China, while at the same time we see clear financial and economic growth. As the objective of proper corporate governance is theoretically to assure efficient allocation of resources, it seems there is a missing link in the ability of financial theory to explain the pattern of a weak governance structure but strong economic performance in China.

The limited research on the influence of corporate governance on firm performance is surprising, given the increasing number of Chinese firms listed on the exchanges and the growing amount of data available. The unusual Chinese corporate structure reflects a mix of socialistic and market-oriented economies. The role that government plays in corporate governance issue in China's emerging financial market is assuredly important. Future research in this area will be fruitful.

\subsection{Initial public offerings (IPOs)}

With regarding to Chinese IPOs, the research is gaining momentum. Apparently, data on the costs of IPOs and the impact of investment banks in valuation are unavailable, suggesting great potential for future research.

Mok and Hui (1998) provide one of the early studies in Chinese IPOs. Mok and Hui document that A-share firms issuing IPOs in Shanghai report an underpricing of $289 \%$ as compared to a $26 \%$ underpricing for B-share firms. In a similar IPO study, Chan, Wang, and Wei (2004) find that the average underpricing for A- and B-share IPOs are $178 \%$ and $11.6 \%$ respectively. Three factors are suggested to explain the underpricing. First, firms with more 
government ownership are found to be less underpriced, suggesting that higher government ownership is a good proxy for reduced information asymmetry between firms and investors. Second, firms with longer periods between offering and listing are associated with more underpricing. This result suggests that this time lapse may be a proxy for higher risk, which increases the underpricing. Finally, a smaller IPO appears to be subject to more underpricing. Following the IPO, these smaller IPO firms appear to outperform the overall market for a long time. In another IPO study of Chinese firms, Su (2004) presents evidence to suggest that IPO underpricings is positively correlated with pre-IPO leverage and insider ownership.

The early Chinese IPO studies focus on the documentation of the IPO process and returns of IPO to investors. Besides documenting the IPO returns, there are other focuses in IPO studies. First, there are IPO-related studies regarding how IPOs affect other aspects of the issuing firms. Poon, Firth, and Fung (1998) use an event study methodology to document adverse effects of IPOs of B-shares on the prices of A-shares issued. A decline in prices may be partially explained by a reduction in investor base and liquidity. Chen and Firth (1999) examine the accuracy of profit forecasts made by firms during the IPO process. They find that profit forecasts are moderately accurate, and are better than times series extrapolations for the six-year period: 1991 to 1996. Market values of firms are positively related to the forecast errors, implying that investors can rationally anticipate the direction of the forecast errors. Aharony, Lee, and Wong (2000) examine Chinese state-owned enterprises that issued IPOs in the B-share domestic market, and the H-share (offshore) Hong Kong market during 1992 and 1995. They document that earnings of firms in unprotected industries (those under the supervision of state or provincial governments) decline more than those in protected industries (those under the direct supervision of the State Council) after an IPO, and so do accounting accruals. 
Second, there are studies examining the validity of various IPO hypotheses. Su and Fleisher (1999) test empirically the signaling and bribery and lottery allocation theories in underpricing of IPOs in China. Su (2004) examines the validity of adverse selection (winner's curse) model and signaling model using IPO data in China. Su and Fleisher (1999) offer evidence to support the signaling theory and Su (2004) presents evidence supporting both the adverse selection and signaling models.

Third, there are several studies on IPO firm performance before and after IPO. Chen, Firth, and Kim (2000) examine the post-issue performance of IPOs in China using data on 277 A-share and 65 B-share IPOs during the period 1992-1995. Specifically they examine the initial returns (offering date to first trading date) and aftermarket returns (one, two or 3yrs after IPO exclusive of initial return) for both A-and B-share. They find that the initial returns on A-share IPOs are very high than those found in mature markets, after market return is positive for the first year and negative in the second and third year after listing. The initial return for B-share IPOs is similar to the ones found in mature markets and after market return is negative. A-share IPOs outperform B-share IPOs during the initial return period and also during the post issue period up to 3 years. Chen and Shih (2003) investigate pre and post-IPO financial and operating performance of Chinese firms using a sample of 884 firms during the period 1995 to 1999. Chen and Shih use operating revenue, growth in net profit, EPS, ROE, current ratio and quick ratio as operating, profitability and stability indicators. Chen and Shih find that except for EPS and ROE these indicators tend to remain the same or deteriorate post IPO. Chen and Shih conclude that there is no significant change in the operational and financial performance of the firms in postIPOs, and in some cases may even deteriorate. The findings of Chen and Shih suggest that the Chinese IPO firms are underdeveloped in corporate governance mechanism and submission of 
exaggerated financial numbers for stock listing and IPO. Haung and Song (2005) investigate financial and operating performance of $\mathrm{H}$-share firms before and after going public. They find that H-share firms' performance declined after listing. They attribute this to the domination of negative IPO effect over positive privatization effect. For comparison, they investigated the performance of newly listed private firms (control sample) and found that their performance declined more than that of $\mathrm{H}$-share firms. From this, they conclude that privatization has positive effect on a company's performance, which tends to offset some of the negative IPO effect.

In summary, the IPO studies become more comprehensive and are able to address other IPO-related issues of the issuing firms in recent years. Given that a lot of companies are interested in listing their shares, the IPO research has a lot of potential. The challenge remains the availability of data on the companies and the transparency of the IPO process.

\section{A Bank-Based Financial System}

China’s emerging financial market illustrates some interesting issues related to a bankbased financial system as compared to a market-based financial system. Allen, Qian, and Qian (2005) examine the connection between China's economic growth and the development of formal governance, legal, and financial systems They examine three sectors of the Chinese economy: (1) the State sector (SOEs); (2) the listed sector (includes all the firms listed in the exchanges); and (3) the private sector (includes all other firms with private and local government control). They report that the "law-finance-growth" nexus (i.e., well developed legal and financial system required for economic growth) as suggested by the existing literature works well for the first two sectors. What is puzzling is that the private sector has dominated the other two in terms of growth and size, in spite of the poorer legal protection and financing channels 
available compared to the other two sectors. Allen, Qian, and Qian argue that China's bankbased financial system is effective, and provides informal financing channels and governance mechanisms to support the growth of the economy.

As banks have performed reasonably well historically in credit allocation decisions, governments can seek to achieve economic objectives through regulation of banks. As China implements economic plans to move toward a market-oriented economy, Chinese banks become critical in supporting this goal. Chinese banks have come to play a more important role than the financial market in resource allocation, and the banking literature largely focuses on how to improve efficiency of the banking sector (such as non-performing loans issues and moral hazard problems).

Lo (2001) discusses China's gradual banking reforms in two phases. The first phase (1978-1992) created a market-oriented banking system while maintaining the legacy of central planning. The second phase (1992-present) eliminated the central planning, on banks and established a full-fledged modern banking system. Lo argues that today’s non-performing loan problem is the result of a gradual approach to banking reform.

$\mathrm{Li}$ and Yau (2001) first present a framework linking the current banking reforms to the stability of the Chinese currency and the overall economy. They discuss various bank reforms, including establishment of asset management to reduce non-performing loans and liberalize interest rates. They also outline challenges to recent bank reforms such as World Trade Organization (WTO) access and inadequate corporate governance structures.

Huang (2002) discusses the non-performing bank loans, which are unlikely to lead a financial crisis in China because of restrictions on the capital account. As China became a 
member of the World Trade Organization in 2001, it was argued that the Chinese state-owned banks need to be broken up to face global competition from foreign banks.

Bonin and Huang (2002) describe the threats of foreign bank entry into China after it joined WTO in 2001. Various responses of Chinese banks to foreign banks are analyzed, including establishment of asset management dealing with bad bank loans and the need for supervision.

Fung (1999) examines various banking reforms in China and the challenges of foreign competition for domestic banks. The success of the system depends on continued banking reforms and the privatization of Chinese banking.

Li and Mehta (2001) analyze the profitability of Chinese banks and the impact of overhanging bad debt. They propose various methods to improve bank solvency and profitability through restructuring at both the individual bank level (e.g., asset-liability management) and the industry level (e.g., enforcement of standards for supervision and policies regarding the entry of foreign banks).

Wong and Wong (2001) analyze the concentration ratio, profitability, and balance sheet structures of Chinese banks in general and the four major state-owned banks in particular. They too present proposals that can improve the banking industry, such as reducing governmentimposed impediments (such as interest rate controls), increasing bank autonomy, and promoting bank privatization.

Li and Peng (2002) discuss the money market (i.e., the interbank market) and its growth. A growing government bond repurchase market is particularly noticeable in response to China's monetary policy establishing liquidity needs of banks. Fung and Liu (2004) describe the recent development of the Chinese interbank market, which has grown substantially over the past 
several years. Trading volume jumped to RMB 11.84 trillion in 2002 from RMB 446.3 billion in 1997. The new RMB market for Chinese and foreign banks is another cornerstone in the future growth of China's interbank market.

Leung, Rigby, and Young (2003) and Leung, Young, and Rigby (2003) use a survival analysis to examine the factors affecting foreign bank entry in China and their profitability. Entry factors include the foreign bank's size, international diversification, and location. As foreign banks deal primarily with trade issues in China, the trade relation proxy is found to be important in the entry decision. Profitability factors include the foreign bank's size, number of branches, level of foreign direct investment, and the cost of international financing.

Because Chinese banks are heavily regulated, and bank entry is highly restrictive, research on Chinese banks focuses primarily on either reforms or foreign entry into the Chinese economy. Individual bank data are largely absent, and detailed statistical analysis of individual bank performance is unavailable, and so the studies in this area are largely descriptive in nature. Banking research is still in its early stages. The issue of problem bank loans will surface and present challenges to China. More data are needed for research on performance at the individual bank level and industry level in order to provide more evidence in terms of bank efficiency and institutional characteristics.

\section{Interactions of Goods and Financial Market}

Another interesting pattern in the Chinese emerging financial system is the way the goods market affects the behavior of the financial market (and vice versa) in an imperfect market. When Chinese firms issue A and B-shares, we observe underpricing for both initial public offering (IPO) issues, but much more severe underpricing for A-shares [see Mok and Hui (1998)]. This is likely due to information asymmetry between the two markets. 
Mok and Hui (1998) find that a higher government ownership, a proxy for reduced information asymmetry and better reliability, is found to have lower underpricing in IPOs. Similarly, Tian (2002) provides empirical evidence to suggest that the Chinese government uses a mandatory delay of flotation on the stock exchange for public trading of IPOs. Tian calls this phenomenon as a "forced underpricing" and argues that it is the political interests of the reformist government to see a successful development of a stock market.

Gordon and Li (2003) show that the optimal policy that maximizes tax revenue from securities income in China is to take advantage of the segmented markets where prices are higher for domestic investors than foreign investors. Huang and Fung (2004) provide a model that the major stockholders with non-floatable shares maximize their book values to exploit the liquidity premium (the price differential between floatable and non-floatable shares). The model is able to explain some commonly seen patterns in China- why firms prefer to issue floatable equity shares rather than other types of financings, why there are no stand-alone mergers or acquisitions between listed companies, and why firms restructure through mergers and acquisitions and then refinance through floatable equity issues.

Cull and Xu (2005) investigate whether property rights or access to external finance better explains a firm's profit reinvestment decisions in the Chinese context. Using data from a survey of Chinese firms conducted by the World Bank for the period 2000-2002, Cull and Xu find that both the property rights and access to external finance are very important in explaining Chinese firm's profit re-investment decisions.

\section{A Managed Foreign Exchange Regime}

Foreign exchange market studies examine undervalued or overvalued issues of the Chinese currency because of the nature of a fixed exchange rate. A swap market and a non- 
deliverable forward market illustrate how market participants have overcome market impediments by creating new instruments.

Huang and Wong (1996) investigate China’s foreign exchange market before and after the 1994 harmonization of the official and the swap exchange rates. Through foreign exchange adjustment centers, foreign enterprises short foreign currency can meet their needs by purchasing at a negotiated rate foreign exchange quotas from enterprises that have surplus foreign exchange quotas. This is called the swap market. Yang and Leatham (2001) examine the way free currency convertibility under the current account affects the linkage between the official and swap market exchange rates. They find an improved information connection between the official and swap rates with the free current account regime.

Chang (2002) discusses a waning confidence in the Chinese currency after the 1997 Asian financial crisis and argues that the Chinese government can defend the currency in the short run. In the event expansionary monetary and fiscal policies are implemented, it would be more costly for the government to maintain the fixed exchange rate system.

McKinnon and Schnabl (2003) demonstrate an unwarranted recent pressure for appreciation of the Chinese currency. They argue that appreciation of the currency would lead to repeated events of appreciation and would result in severe deflation and a zero-interest liquidity trap.

Fung, Leung, and Zhu (2004) discuss the development of the offshore non-deliverable forward (NDF) market for the Chinese currency. Different maturities of the NDF are obtainable. Multinational banks and brokerage firms offshore offer currency trading and services for firms doing business in China, thus allowing them opportunities to hedge Chinese currency risk, not available in the domestic market. 
The research in the foreign exchange market in China is also in early stage. There are ample research opportunities in this area.

\section{Integration with the Global Market}

Finally, it is interesting to see how China’s financial market has emulated and integrated over time with more mature financial markets [Laurence, Cai, and Qian (1997) and Xu (2000)]. China policymakers have selectively adopted some practices from the U.S. Financial research over the last ten years addressed the issue of government's role and the influence of the welldeveloped U.S. financial markets on the Chinese financial markets [Xu and Fung (2002), and Chan, Fung, and Leung (2004)]. During the development of the Chinese futures markets in the early 1990s, Chinese officials solicited advice from Chicago Board of Trade (CBOT) executives to help in setting up its first futures exchange [Williams, Peck, Park and Rozelle (1998)]. Instead of the open outcry system in CBOT, China adopted an electronic trading system, which appears to be more transparent.

Fung, Leung, and Xu (2003) document the patterns of information flows for three commodity futures ((copper, soybeans, and wheat) traded in both U.S. and Chinese market. They find that the U.S. futures market plays a dominant role in transmitting information to the Chinese market for two commodities (copper and soybeans) that are subject to less government regulation and fewer import restrictions in China. For the heavily regulated and subsidized wheat commodity, the results indicate that the U.S.-China futures markets are highly segmented in pricing, although there is some information transmission via volatility spillover across markets.

Chan, Fung, and Leung (2004) examine the intraday volatility of four futures contracts on Chinese futures exchanges (copper, mungbeans, soybeans, and wheat). Returns are found to have 
asymmetric effects on volatility, meaning that negative returns have more of an effect on volatility than positive returns do. Volume is positively related to volatility; open interest is negatively related to volatility; and the extent of large volume traders' participation is also positively related to volatility. The strong relationship of volatility to open interest, volume, and

returns is more pronounced in recent years than earlier years. The result is likely due to government regulations that make the futures market more transparent by disclosing more information to market participants. The research of Chan et al. suggests that many issues remain to be explored as to the role of government in the behavior of Chinese futures markets.

The research in futures market suggests the impact of global financial market on Chinese financial market. As China becomes more open, we shall see the integration becomes more noticeable.

\section{Concluding Remarks}

The amount of financial research on China in the last fifteen years mirrors the rapid development of financial markets in China. Our work summarizes these studies, and generalizes some interesting patterns. We recognize characteristics of an emerging market that is apparently imperfect and incomplete. We can see interactions between the financial market and the goods market, the working of completing the market, and the evolution of an emerging market that emulates and is becoming integrated with the world's mature market.

We note that government plays a particular important role in an emerging market, because it can establish a transparent and fair environment that allows transactions to take place. A competitive financial market cannot function well by itself without some formal or informal structure. The Chinese government's cautious approach toward its financial market development presents a valuable lesson for policymakers in developing countries. At the same time, the 
impediments the Chinese government imposes provide us other lessons. They can give us a better understanding of how impediments affect pricing and market behavior and some insight into interactions between the financial market and the goods market in an incomplete market.

Traditional financial theory cannot completely explain corporate governance and economic growth. Our review helps us see the missing links. There are many areas of financial issues in China unexplored, including bank's monitoring roles, market efficiency issues (how fast information can reflect news), pricing of IPOs, seasoned equity and rights offerings, capital structure and corporate governance effects on valuation, and the microstructure issues in the financial markets (futures and equity markets). Analysis of the gaps in the research should provide some stimulus for expanding future research. 


\section{References}

Aharony, J., J. Lee, and T.J. Wong, 2000. Financial packaging of IPO firms in China, Journal of Accounting Research, 38, 103-126.

Allen, F., J. Qian, and M.Qian, 2005. Law, finance, and economic growth in China, Journal of Financial Economics, forthcoming.

Bailey, W, 1994. Risk and return on China's new stock markets: some preliminary evidence, Pacific-Basin Finance Journal, 2, 243-260.

Bergstrom, C. and E. Tang, 2001. Price differentials between different classes of stocks: An empirical study on Chinese stock markets, Journal of Multinational Financial market, $11,407-426$.

Bonin, J. and Y. Huang, 2002. Foreign entry into Chinese banking: Does WTO membership threatens domestic banks? The World Economy, 1077-1093.

Burkart, M., F. Kubler, and K. Schmedders, 2003. Family firms, Journal of Finance, 58, 21672201.

Chakravarty, S., Sarkar, A. and L. Wu, 1998, Information asymmetry, market segmentation and the pricing of cross-listed shares: Theory and evidence from Chinese A and B shares. Journal of International Financial Markets, Institutions and Money, 8, 325-355.

Chan, Kam C, L. Cheng, and J. Fung, 2001. Ownership restriction and stock price behavior in China, Chinese Economy, 34, 29-48.

Chan, Kam C., H.G. Fung, and W.K. Leung, 2004. Intraday Volatility Behavior in Chinese Futures Markets, Journal of International Financial Markets, Institutions, and Money, 14, 491-505.

Chang, G.H., 2002. The stability of the RMB in the post-Asian crisis period, in Financial Markets and Foreign Direct Investments in Greater China, Fung, H.G. and K.H. Zhang (eds.), New York: M.E. Sharpe Publishing Co.

Chen, C. H. and H. T. Shih, 2003, Initial public offering and corporate governance in China's transitional economy, NBER Working Paper \# 9574.

Chen, Gongmeng and M. Firth, 1999. The Accuracy of profit forecasts and their roles and associations with IPO firm valuations, Journal of International Financial Management and Accounting, 10, 202-226.

Chen, G., Firth, M. and J. Kim, 2000. The post-issue market performance of initial public offerings in China's new stock markets, Review of Quantitative Finance and Accounting 
14, 319-339.

Chen, J., 2001, Ownership structure as corporate governance mechanism: Evidence from Chinese listed companies, Economics of Planning, 34, 53-72.

Chen, J. Jean, 2004. Determinants of capital structure of Chinese-listed companies Journal of Business Research, 57, 1341- 1351.

Chui, A., and C. Kwok, 1998, Cross-autocorrelation between A shares and B shares in the Chinese stock market, Journal of Financial Research, 21, 333-353.

Cull, R., L. C. Xu, 2005. Institutions, ownership, and finance: the determinants of profit reinvestment among Chinese firms, Journal of Financial Economics, forthcoming.

Fernald J. and J.H. Rogers, 2002. Puzzles in the Chinese stock market, Review of Economics and Statistics, 416-432.

Friedmann, R. and W. Sanddorf-Köhle, 2002. Volatility clustering and nontrading days in Chinese stock markets. Journal of Economics and Business, 54, 193-217.

Fung, H.G., 1999. Chinese banking: challenges and opportunities in the new millennium, Business Forum, 24, 2-6.

Fung, H.G., W. Lee, and W.K. Leung, 2000. Segmentation of the A- and B-share Chinese equity markets, Journal of Financial Research, 1875-1902.

Fung, H.G. and W.K. Leung, 2001. Chinese financial liberalization: implications for corporate governance, Chinese Economy, 34, 5-14.

Fung, H.G. and W.K. Leung, 2002. The A- and B-share Chinese equity markets: segmentation or integration, in Financial Markets and Foreign Direct Investments in Greater China, Fung, H.G. and K.H. Zhang (eds.), New York: M.E. Sharpe Publishing Co.

Fung, H.G., W.K. Leung and X.E. Xu, 2003. Information Flows between the U.S. and China Commodity Futures Trading, Review of Quantitative Finance and Accounting, 2003, 21, 267-285.

Fung, H.G. and WK. Leung, and J. Zhu, 2003. Non-deliverable forward market for Chinese RMB: a first look, Working paper, University of Missouri-St. Louis.

Fung, H.G., and G. Liu, 2004. China's financial reform in banking and securities markets, forthcoming in China and the Challenge of Economic Globalization: The Impact of WTO Membership, Fung, H.G., C. H. Pei, and K. H. Zhang (eds.), New York: M.E. Sharpe.

Fung, H.G., 2005. China's foreign trade and investment: an overview and analysis, China and World Economy, 13, 3-16. 
Gordon, R.H. and W. Li, 2003. Government as a discriminating monopolist in the financial market: the case of China, Journal of Public Economics, 283-312.

He, Y., Wu, C. and Y. Chen, 2003. An explanation of the volatility disparity between the domestic and foreign shares in the Chinese stock markets. International Review of Economics and Finance 12, 171-186.

Huang, G. and C.Y.P. Wong, 1996. Unification of China's foreign exchange rates, Contemporary Economic Policy, 14, 42-57.

Huang, Y. 2002, Is meltdown of the Chinese banks inevitable? China Economic Review, 13, 382-387.

Huang, A.G. and H.G. Fung, 2004. Stock ownership segmentation, floatability, and the constrained investment banking in China, China and World Economy, March-April, 12, 66-78.

Huang, G. and F.M. Song, 2005. The financial and operating performance of China's newly listed H-firms, Pacific-Basin Finance Journal, 13, 53- 80.

Kang, J., Liu, M. and S. Ni, 2002, Contrarian and momentum strategies in the China stock market: 1993-2000, Pacific-Basin Finance Journal, 10, 243-265.

Karolyi, G.A. and L. Li, 2003. A resolution of the Chinese discount puzzle, Working paper, Ohio State University.

Laurence, M., F. Cai, and S. Qian, 1997. Weak-form efficiency and causality tests in Chinese stock markets, Multinational Financial Journal, 1, 291-307.

Lee, C.F. and Rui, O. 2000. Does trading volume contain information to predict stock returns? Evidence from China's stock markets, Review of Quantitative Finance and Accounting, 16, 341-360.

Lee, C.F., G. Chen, and O. Rui, 2001. Stock returns and volatility: an empirical study of the Chinese stock market, Journal of Financial Research, 24, 523-543.

Leung, M.K., T. Young, and D. Rigby, 2003. Explaining the profitability of foreign banks in Shanghai, Managerial and Decision Economics, 24, 15-24.

Leung, M.K., D. Rigby, and T. Young, 2003. Entry of foreign banks in the Peoples’ Republic of China: A survival analysis, Applied Economics, 35, 21-31.

Li, B. and D. Mehta, 2001. Restructuring of Chinese banking industry, China and World Economy, 3, 50-55. 
Li, J. and J. Yau, 2001. China's banking reform: a single step in a thousand-mile journey, International Journal of Business, 6, 87-110.

Li, Y. and X.Y. Peng, 2002. The money market in China: theory and practice, China and World Economy, 3, 3-10.

Liu, X., Song, H., and P. Romilly, 1997, Are Chinese stock markets efficient? A cointegration and causality analysis, Applied Economics Letters, 4, 511-515.

Liang, N. and J. Li, 2003. Board structure and firm performance: an empirical study of China's private firms, China and World Economy, 4, 51-59.

Lo, W.C., 2001. A retrospect on China’s banking reform, Chinese Economy, 34, 5-28.

Long, D., Payne, J. and C. Feng, 1999, Information transmission in the Shanghai equity market. Journal of Financial Research, 22, 29-45.

McKinnon, R. and G. Schnabl, 2003. China: a stabilizing or deflationary influence in East Asia? The problem of conflicted value, Working paper, Stanford University.

Mok, H. and Y. Hui, 1998. Underpricing and aftermarket performance of IPO in Shanghai, China, Pacific-Basin Finance Journal, 8, 453-474.

Otchere, Isaac and Z. Zhang, 2001. Privatization, efficiency and intra-industry effects: analysis of China's privatization, International Review of Finance, 2, 49-70.

Poon, W., M. Firth, and H.G. Fung, 1998. Asset Pricing in segmented capital markets: Preliminary evidence from China-domiciled companies, Pacific-Basin Finance Journal, 6, 307-319.

Poon, W. and H. Fung, 2000. Red chips or H shares: which China-backed securities process information the fastest? Journal of Multinational Financial Management, 10, 315 - 343.

Qi, D, W.Y. Wu, and H. Zhang, 2000. Ownership structure and corporate performance of partially privatized Chinese SOE firms, Pacific-Basin Finance Journal, 8, 587-610.

Stijn C. and L. Laeven, 2003. Financial development, property rights and growth, Journal of Finance, 58, 2401-2436.

Su, D., 1999. Ownership restrictions and stock prices: evidence from Chinese markets, Financial Review, 34, 37-56.

Su, D., 2003. Stock price reactions to earnings announcements: evidence from Chinese markets, Review of Financial Economics, 12, 271-286. 
Su, D., 2004. Adverse-selection versus signaling: evidence from the pricing of Chinese IPOs, Journal of Economics and Business 56, 1-19.

Su, D. and B. Fleisher, 1998, Risk, return and regulation in Chinese stock markets, Journal of Economics and Business, 50, 239-256.

Su, D. and B. Fleisher, 1998. Information, regulation and volatility in Chinese stock markets, Journal of Economics and Business, 50, 239-256.

Su, D. and B. Fleisher, 1999. An empirical investigation of underpricing in Chinese IPOs, Pacific-Basin Finance Journal 7, 173-202.

Su, D. and B. Fleisher, 1999. Why does return volatility differ in Chinese stock markets? PacificBasin Finance Journal, 7, 557-586.

Sun, Q. and W.H.S. Tong, 2000. The effect of market segmentation on stock prices: the China Syndrome, Journal of Banking and Finance, 24, 1875-1902.

Sun, Q., W.H.S. Tong, and J. Tong, 2002. How does government ownership affect firm performance? Evidence from China's privatization experience, Journal of Business Finance and Accounting, 29, 1-26.

Sun, Q. and W.H.S. Tong, 2003. China share issue privatization: the extent of its success, Journal of Financial Economics, 70, 183-222.

Wang, C and S. Chin, 2004. Profitability of return and volume-based investment strategies in China's stock market, Pacific-Basin Finance Journal, 12, 541-564.

Wang, P., Liu, A., and P. Wang, 2004. Return and risk interactions in Chinese stock markets. Journal of International Financial Markets, Institutions \& Money, 14, 367-384.

Wang, Z., A. M. Kutan, and J. Yang, 2004. Information flows within and across sectors in Chinese stock markets, Quarterly Review of Economics and Finance, forthcoming.

Watanabe, M., 2002. Holding company risk in China: a final step of state-owned enterprises reform and an emerging problem of corporate governance, China Economic Review, 13, 373-381.

Wei, Z., O. Varela, and M.K. Hassan, 2002. Ownership and performance in Chinese manufacturing industry, Journal of Multinational Management, 12, 61-78.

Wei, Z., O. Varela, J. D'Souza, and M.K. Hassan, 2003. The financial and operating performance of China's newly privatized firms, Financial Management, 32, 107-126. 
Williams, J., A. Peck, A. Park, and S. Rozelle, 1998. The emergence of a futures Market: Mungbeans on the China Zhengzhou Commodity Exchange, Journal of Futures Markets, 18 , 427-448.

Wong, Y.C., and M. L. Wong, 2001. Competition in China’s domestic banking industry, Cato Journal, 21, 19-41.

Xu, C.K., 2000. The microstructure of the Chinese stock market, China Economic Review, 11, 79-97.

Xu, X. E, and H.G. Fung, 2002. Information flows across markets: evidence from China-backed stocks dual-listed in Hong Kong and New York, Financial Review, 37, 563-588.

Xu, Y. and Y. Wang Y. 1999. Ownership Structure and Corporate Governance in Chinese Stock Companies, China Economic Review, 10, 75-98.

Yang, J. and D. J. Leatham, 2001. Currency convertibility and linkage between Chinese official and swap market exchange rates, Contemporary Economic Policy, 19, 347-359.

Yang, J., 2003. Market segmentation and information asymmetry in Chinese stock markets: a VAR analysis, Financial Review, 38, 591-609.

Yeh, Y. and T. Lee, 2000. The Interaction and volatility asymmetry of unexpected returns in the greater China stock markets, Global Finance Journal, 11, 129-149.

Yeh, Y.H., T.S. Lee, and J.F. Pen, 2002. Stock returns and volatility under market segmentation: The case of Chinese A and B shares, Review of Quantitative Finance and Accounting, 18, 239-257 